\title{
STRENGTHENING LOCAL ECONOMY THROUGH COMMUNITY-BASED TOURISM IN GOVERNANCE PERSPECTIVE (Study at Sidomulyo Tourism Village, Batu City)
}

\author{
Rifka Aulya ${ }^{1}$, Lely Indah Mindarti ${ }^{2}$, Fadillah $\mathrm{Amin}^{3}$ \\ 1 Master Student, Faculty of Public Administration, University of Brawijaya \\ 2,3Lectures, Faculty of Public Administration, University of Brawijaya
}

\begin{abstract}
Tourism has an important role to create and expand the employment opportunities, promote development and increase the district own source revenue, enrich local culture, and preserve the environment. Batu City is one of famous tourism destinations in Indonesia which has a high potential in natural and agricultural tourism attraction. The tourism development in Sidomulyo Tourism Village emphasizes on community empowerment. One of the problems that still faced by its people is the capital limitation, inadequate facilities, lack of human resources and technology. Therefore, the implementation of tourism village should be based on community based tourism that emphasizes self-reliance and community empowerment. Community-Based Tourism (CBT) implementation has the purpose to develop tourism industry; promote rural tourism based on local community empowerment; create jobs; reduce poverty; build an independent and resilient society; create an innovative human; and improve cross-sector cooperation in the tourism village development. Implementation of CBT in Sidomulyo couldn't be separated from the role of the various stakeholders. It is accordance with the principles of governance that the implementation of development which involving all actors namely the state (government), private sector, and society. The process in realizing the independent community through community empowerment program of tourism with the concept of community based tourism may be optimized for their several contributing factors. Some things become a supporting factor due to give a positive contribution to the implementation of community-based tourism.
\end{abstract}

Keywords: Local Development, Tourism, Governance, Batu City, Indonesia.

\section{INTRODUCTION}

Development in developing countries is often associated with efforts to increase the per capita income. With rising incomes, it is expected the problems of poverty, unemployment, and inequality of income distribution can be solved. However, basically the development is not just a purely economic phenomenon. Development is not indicated by the achievement of economic growth achieved by the country, but more than that development has a broad perspective. This is also confirmed by the opinion of Kuncoro (1987: p. 45) which says that in the development process, in addition to considering aspects of growth and equity, also consider the impact of economic activity on the social life of the community. To achieve the goal of a comprehensive development is not easy for governments of developing country such as Indonesia. There are 
still many problems faced by the Indonesian government to implement developments, particularly in improving the local economy. One of the factors that become the challenge of economic growth in Indonesia is the inequality of income distribution. Development is still centralized and massively implemented only in big cities, resulting in tremendous inequality between urban and rural communities, especially in economic terms.

The issue of development disparities become an irony that creates a gap between the rich and the poor because of economic inequality, affect the high and low education due to inequality of education, and also make the rural and urban development due to inequality region. Rahadhan and Fitranto (2006: p. 2) state that:

"Rural-urban dichotomy eventually becomes a significant representation in displaying the results of inequality patterns of development in developing countries. The village represents the agricultural sector, the uneducated, poverty and lack of early modern. Instead, the city becomes the representation of industry, intelligentsia, the capitalization of capital, wealth, and progress ".

From their opinion, it can be seen that the villagers are helpless and just become a victim of exploitation of resources and has developed very slowly.

The key question for development problems in rural areas is how the government's efforts to overcome the widening polarization from economic inequality of rural and urban communities. The enactment of Law Number 23/ 2014 on Regional Government insists that the central government seeks to give authority to the regions to plan and organize the territory in accordance with its potential. This means that the economic distribution can be evenly distributed throughout the community. This law will become an opportunity for the regions to improve the welfare of its people, because if the development is still centralized by government, then the area that is far away from the city will be left out from development. The existence of this law is a fresh breeze to the achievement of an independent village and enables them to work together with the city.

With local autonomy, local governments will have the authority to manage the resources that available in the region, which includes natural resources, artificial resources, and human resources available in the region and is also responsible for maintaining the environment in accordance with the legislation. In Government Regulation Number 38/ 2007 on the Coordination of the Central Government and Local Government, divides the central and regional affairs, ranging from administrative matters to the management of natural resources. These laws regulate some affairs as a matter of choice by the region as stated in article 7, paragraph 3 and 4, which states that the affairs of the Local Government include: marine and fisheries, agriculture, forestry, energy and mineral resources, tourism, industry, trade, and transmigration. From eight of local government's affairs, one of the sectors that contributed the greatest economic potential is tourism, especially if the tourism area can emphasize the potential and its local wisdom.

Tourism has an important role to create and expand the employment opportunities, promote development and increase the District Own Source Revenue, enriching local culture, and preserve the environment. During this time, tourism has contributed to the entry of foreign exchange and District Own Source Revenue in some areas. Nationally, tourism is an important 
Rifka Aulya, dkk, Strengthening Local Economy Through Community-Based Tourism In Governance Perspective (Study at Sidomulyo Tourism Village, Batu City) |13

economic sector which in 2009, tourism ranks third in terms of foreign exchange earnings after oil and gas, and palm oil. Based on the data reports the Ministry of Tourism and Creative Economy also revealed that in 2010, the tourism sector ranks fourth with total foreign exchange earnings amounted to 7603.45 US Dollars. Developed and developing tourism will attract the local tourists and overseas one. In fact, tourism development can encourage economic growth in other sectors such as hospitality, inn, restaurants, services, agriculture and others that encourage economic growth and increase in Gross Domestic Product (GDP).

One of the area in Indonesia which is famous for its natural beauty and tourism is Batu City, East Java. Batu City is able to develop the tourism sector as a leading sector that uses the potential of its area to attract foreign tourists to visit. This gives an impact on economical sector of Batu City that has increased from year to year. The economic improvement can be seen on the Gross Domestic Product achievement as the opinion of Prishardoyo (2008) explain that the acceleration of economic growth of a region is shown by using the rate of GDP enhancement (Gross Domestic Product). This means that GDP per capita level of society development often achieved as a measure of success of a region in achieving the goal of creating economic development. The economic enhancement of Batu City will be described in the following table.

Table 1 Progress of Total GDP in Batu City at Current and Constant Market Prices Year 2009-2010

\begin{tabular}{|c|c|c|c|c|c|c|}
\hline \multirow{2}{*}{$\begin{array}{c}\text { GDP Per } \\
\text { capita }\end{array}$} & \multicolumn{6}{|c|}{ Year } \\
\hline & 2009*) & 2010*) & 2011*) & $2012 *)$ & $2013 * *)$ & $2014 * * *)$ \\
\hline (1) & (2) & (3) & (4) & (5) & (6) & (7) \\
\hline Current & 11.555 .130 & 17.119 .030 & 19.220 .030 & 21.507 .900 & 25.369 .170 & 28.559 .337 \\
\hline Constant & 7.079 .610 & 7.530 .570 & 8.042 .890 & 8.606 .180 & 9.189 .390 & 9.678 .279 \\
\hline Note & : *Revised & mber $* * \mathrm{~T}$ & porary $\mathrm{Nu}$ & ber $* * *$ Pro & ction Numb & (be treated \\
\hline
\end{tabular}

Based on the table above, it is known that the Batu City gross domestic income has increased from year to year. While, local revenues (Local Own-Source Revenue growth) growth of Batu City can be seen in the following table.

Table 2 Total Own-Source Revenue of Batu City Year 2011 and 2012

\begin{tabular}{|c|c|c|}
\hline Total Own-Source Revenue & 2011 & 2012 \\
\hline Regional Tax Sector (Thousand & $13.041 .682,5$ & $16.985 .755,5$ \\
Rupiahs) & 58 & 80 \\
\hline $\begin{array}{c}\text { Regional Retribution Sector } \\
\text { (Thousand Rupiahs) }\end{array}$ & 4.015 .000 & 4.416 .858 \\
\hline
\end{tabular}

Source: Central Bureau Statistic of Batu City year 2013 
14|Ad'ministrare, Vol. 3 No. 2, 2016

Based on the table above, it can be seen that the Total Regional Own-Revenue of Batu City increased from year 2011 amounted from Rp. 13,041,682.558 to Rp. 16,985,755.580 in 2012 of a regional tax sector. Whereas the retribution sector has increased from Rp. 4.015.000 in 2011 to Rp. 4,416,858 in 2012. One of the sectors that drive the increasing total revenue is from tourism as the icon of Batu City which they are very famous in tourism.

To maintain the tourism potential, The Government of Batu City implement various policies such as opening wide variety of investments from the private sectors. However, it is becoming like a boomerang to the people of Batu itself because with open access to investments outside parties (private sector), it makes the city more inclined to artificial tourism and the construction of supporting facilities like hotels, restaurants, and so on. Ultimately, it will be displacing and cause an agricultural land conversion of Batu City. Before a lot of artificial tourism, Batu City is famous with natural and agricultural one. The decreasing of agricultural sector in Batu City can be seen in the following table.

Table 3 Economic Growth of Gross Regional Product in Batu City from 2009 to 2012

\begin{tabular}{|c|c|c|c|c|c|}
\hline Sector & 2008 & 2009 & 2010 & 2011 & 2012 \\
\hline (1) & $(2)$ & $(3)$ & $(4)$ & $(5)$ & $(6)$ \\
\hline Agriculture & 6,13 & 6,09 & 5,52 & 4,89 & 4,38 \\
\hline Mining and Quarrying & 6,91 & 5,64 & 6,59 & 6,00 & 5,12 \\
\hline Processing Industry & 6,37 & 5,59 & 6,22 & 6,03 & 6,57 \\
\hline Electricity and Water & 8,66 & 8,93 & 8,95 & 8,88 & 8,98 \\
\hline Building & 11,60 & 12,44 & 12,62 & 13,98 & 13,54 \\
\hline Trade, Hotel and Restaurant & 6,34 & 6,97 & 8,41 & 9,24 & 9,77 \\
\hline Transportation and Communication & 7,75 & 7,19 & 7,68 & 9,03 & 9,26 \\
\hline Finance, Rent, and Company Service & 6,89 & 6,78 & 8,81 & 8,60 & 8,59 \\
\hline Services & 9,19 & 8,43 & 7,08 & 8,51 & 8,37 \\
\hline Total & 6,87 & 6,99 & 7,52 & 8,04 & 8,25 \\
\hline
\end{tabular}

Source: Central Bureau Statistic of Batu City year 2013

Based on the table above, it can be seen that the growth of the economy in Batu City is dominated by the building sector and the trade, hotels and restaurants rather than the agricultural sector. While Batu itself identic with its agricultural which known as ecotourism or agrotourism. However, lately the agricultural sector gets replaced by other sectors. This becomes a contrary to the vision and mission as stipulated in the Batu City Tourism Development Master Plan of 2010-2020. The vision of the Batu City in the Tourism Development Master Plan is the "Realization of Batu City as the center of the Tourism Based on Agriculture Towards Mutual Civil Society" while the first point of Batu mission in this Tourism Master-plan is developing a modern economy in East Java based on agriculture. In the table above also shown that the agricultural sector has decreased every single year. Therefore, to overcome the problems of declining agriculture, Batu city government begins to implement the Tourism Village to develop 
Rifka Aulya, dkk, Strengthening Local Economy Through Community-Based Tourism In Governance

Perspective (Study at Sidomulyo Tourism Village, Batu City) |15

featured local potential in each region of the Batu City. One of them is the Tourism Village in Sidomulyo.

Sidomulyo village is the prettiest village in Batu because it has a wide range of tourism potential which can be developed. The village presents a wide range of tourist options such as views of a wide range of flowers, mountain bike, horseback tours and culinary tours, and the hospitality of local villagers. Tourism in Sidomulyo has a very strategic position, because it is located on the main route in the tourism area of "Selecta Batu", so the village has the potential to be developed into a tourism area as most of the tourists generally prefer a vacation in naturethemed area, and from that point it is expected to attract both local and foreign tourists.

Flowers tourism village in Sidomulyo is a form of implementation of the Regulation from the Minister of Culture and Tourism Number KM.18/ HM.001/ MKP/ 2011 on Guidelines for the National Program for Community Empowerment in Tourism. This regulation is a reference for government agencies at the central and local, private, and community in the implementation of Community Empowerment in Tourism, including tourism village. In this regulation also explain the definition of tourism village as a form of integration between attractions, accommodation and support facilities which are presented in a structure of a society that blends with the procedures and the prevailing tradition. Community empowerment on tourism is part of the national program implementation through community empowerment, capacity building of stakeholders and the provision of direct aid the community in order to improve the welfare of the community with the development of tourism in the: tourism village, the village around the tourist attraction, and villages around tourism businesses center.

Basically, the implementation of Sidomulyo tourism village is in accordance with community-based tourism approach. But in fact, the implementation does not run smoothly and optimally. Community-based tourism in Sidomulyo doesn't implement optimally in accordance with the expectations of government and society, and there are still many obstacles. One of the problems that inhibit the development of rural tourism in Sidomulyo is that the interest still limited in capital, inadequate facilities, human resource is still lacking, and lack of technology. Based on pre-interview research that has been conducted by researcher at the flower market of Sidomulyo, there were many people who say that implementation of tourism village which based on community has a contribution in their income and social welfare. But some of the flower farmers still face several challenges in the implementation of tourism village, such as insufficient facilities for tourists and some other technical obstacles. Therefore, the implementation of rural tourism should be based on community based tourism that emphasizes self-reliance and community empowerment. To determine the contribution of community based tourism in the village Sidomulyo in improving the local economy, the researcher wanted to make observations and analysis on strengthening the local economy in Sidomulyo tourism village with governance perspective on the role as the actor who see governance in contributing to the improvement of the local economy of Sidomulyo society. 
16|Ad'ministrare, Vol. 3 No. 2, 2016

\section{THEORITICAL FRAMEWORK}

\section{Community Based Tourism}

Implementation of tourism in the era of autonomy is inseparable from an active community role in the development of tourism industry in their respective regions. In terms of tourism, it is often referred to as Community-Based Tourism (CBT). As for the definition of CBT according Hadiwijoyo (2012, p. 71) is:

"Tourism which aware of cultural, social, and environmental sustainability. The form of tourism is managed and owned by the community for the community, to help the tourists to increase their awareness and learn about community and the way of life of local communities (local way of life)".

Meanwhile, according to Pinel in Hadiwijoyo (2012, p. 71) says that the CommunityBased Tourism (CBT) is a tourism development model which assumes that tourism should be set off from the consciousness of the values of the needs of the community in an effort to build tourism which more beneficial for the needs, initiatives, and opportunities for the local society, It can be concluded that CBT is a tourism activity which emphasizes the aspects of local communities as subjects or tourism businesses to raise awareness of local values in improving the welfare of the community itself. Community based tourism can be implemented well when considering some elements of natural and cultural resources, community organiztions, management, and learning (Hadiwijoyo, 2012).

The concept of CBT is not different from concept of the development of the tourism sector through community empowerment. Mc. Ardle (1989) in Hikmat (2010, p.3) means that empowerment as a process of decision-making by those who consistently implement the decision. People who have achieved the goal of collective empowered by their independence, even empowered through their own efforts and the accumulation of knowledge, skills and other resources in order to achieve their goals that depend on external aid. Hadiwijoyo (2012, p. 28) states that "Empowerment is a process that runs continuously to improve the capacity and independence of the community and to improve their standard of living".

\section{Role of Governance Actor in Economic and Tourism Development}

Rondinelli and Cheema (2007) stress out that cooperation among government, private sector, and civil society have become important factors in developing and expanding the service network, expand facilities, as well as providing a wide range of basic services such as health, education, and etc. A partnership between government and the private sector can be done by various mechanism, among others, through contracts and concessions, build-to-transfer (buildoperate-transfer), as well as joint efforts such as public private partnership.

Osborne and Gaebler (1993) also explain that governance is a process undertaken jointly to solve public problems and discover what the needs together. Governance not only 
Rifka Aulya, dkk, Strengthening Local Economy Through Community-Based Tourism In Governance Perspective (Study at Sidomulyo Tourism Village, Batu City) |17

emphasizes the government sector, but also involves the private sector and the community, both individuals and groups in a system, procedures, and processes of planning, management, and decision making. Rondinelli and Cheema (2007) also argue that the success of the partnership between the government, private sector, and communities should be designed with care and reflect the common interest. Partnerships should be able to provide benefits for each actor because the three stakeholders in the governance interaction play an important role in regional development.

\section{LED within Development and Public Policy}

Understanding the differentiation between LED with government policy in the previous development tend to hierarchical and top-down approach. Here is the difference between traditional top-down and bottom-up development policy of LED approaches (Rodriguez-Pose, 2001).

Table 1. Differentiation between Traditional Development Policies and Local Economic Development

\begin{tabular}{|l|l|}
\hline \multicolumn{1}{|c|}{ Traditional development policies } & Local Economic Development \\
\hline $\begin{array}{l}\text { 1. Top-down approach in which decisions } \\
\text { about the areas where intervention is } \\
\text { needed are taken in the centre }\end{array}$ & $\begin{array}{l}\text { 1. Promotion of development in all } \\
\text { territories with the initiative often } \\
\text { coming from below }\end{array}$ \\
\hline 2. Managed by central administration & $\begin{array}{l}\text { 2. Decentralized, vertical cooperation } \\
\text { between different tiers of government } \\
\text { and horizontal cooperation between } \\
\text { public and private bodies }\end{array}$ \\
\hline $\begin{array}{l}\text { 3. Sectoral approach to development } \\
\text { to stimulate other economic }\end{array}$ & $\begin{array}{l}\text { 3. Territorial approach to development } \\
\text { (locality, milieu) }\end{array}$ \\
\hline $\begin{array}{l}\text { 5. Financial support, incentives, and } \\
\text { subsidies as the main factor for } \\
\text { attracting economic activity }\end{array}$ & $\begin{array}{l}\text { 4. Maximizing the development potential } \\
\text { of each are to stimulate a progressive } \\
\text { adjustment of the local economic } \\
\text { system to the changing economic } \\
\text { environment }\end{array}$ \\
\hline
\end{tabular}

\section{Tourism and Local Economic Development}

The tourism sectors a positive impact on economic development, both on a local scale and up to national. The potential of tourism in Indonesia has made a significant contribution to 
18|Ad'ministrare, Vol. 3 No. 2, 2016

the state revenue. Tourist attraction that we owned have the ability to attract tourists to visits in various regions that have tourism potential enormously. As described by Mulyaningrum (2005, p.10) that:

"In the economic crisis, the tourism sector is expected to play a role as economic savior, because it is able to generate sufficiently high revenues. Tourism has a multiplier effect (multiplier effect) is high compared to other sectors. Sustainability of tourism activites in one area are influenced by the survival of the economy. Therefore, the need for insight into resource management that generates direct economic benefits for the surrounding communities (local community), the economic growth benefits the people".

Travellers who come to visit on a tourism destination of this region will become a source of income and as a means of equal distribution of income for the population who live in the tourist area. According to Clement cited by Yoeti $(2008$, p. 248$)$ that:

"After the tourists come on a state or tourism location, they would have to spend a dollar on companies such as industrial groups: Accommodations, Food and Beverages, Purchases, Local Transportation, etc. to meet the needs (needs) and desire (wants) during their stay in the area. The money that has been spent by these tourists will not stop circulating, but it is moving from one hand to another. This will create a linkage of various sectors of the tourism sector. One thing to keep in mind that multiplier effect that occur are not the same, but vary from one sector to another".

\section{Community-Based Tourism in Strengthening Local Economic Development}

Community Based Tourism (CBT) as a development approach emphasizes on several aspects such as their form of tourism which provide the opportunity for local communities to control and involved in the management and development of tourism. Then, CBT also gives an opportunity to the public either directly nor indirectly for people who involved in tourism business enterprises to gain benefits. CBT also demanded the implementation of political empowerment and democratization and the distribution of benefits to local communities. It is also characterized by supervision from the government as a regulator to achieve a common goal. Therefore, in the world of tourism, the term CBT is an approach to tourism development which emphasizes the active role of local communities (either directly involved in the tourism industry or not) in the form of providing opportunities (access) in the management and development of tourism that led to the political empowerment through a more democratic life, including the profits from tourism activity that is more equitable for local communities. That idea is a form of critical attention to tourism development which often ignores the rights of local communities in tourist destinations. It is also supported by the opinion Suansri (2003: p. 14) which defines CBT as tourism that takes into account aspects of environmental sustainability, social and cultural as well as a means of community development and environmental conservation (sustainable tourism development). 
Rifka Aulya, dkk, Strengthening Local Economy Through Community-Based Tourism In Governance Perspective (Study at Sidomulyo Tourism Village, Batu City) |19

\section{METHODOLOGY}

This study aims to gain an overview of the implementation of community-based tourism in Sidomulyo as the government's efforts in strengthening local economy in Sidomulyo Village. To obtain the overall and existing condition, then this type of research uses descriptive research with a qualitative approach. The reason the author use this descriptive study is to describe, and explain factual and accurate information on the facts and phenomena that occur systematically.

The research location is a place where researcher does research. Based on the location of this study, researcher has obtained the data and information in accordance with the themes, issues, and focused research that has been set. The research location is in Batu City. The reason of the author chose this location, because Batu is a city that has the potential of nature tourism which very large and has its own local wisdom in developing the tourism potential.

The data source is the place where researcher can find the necessary data and information with respect to this research. For the primary data used in this study are from interviews with:

1. Communities of Sidomulyo village;

2. Officials of Department of Tourism and Culture of Batu City who related to program Tourism Village;

3. Officials of Department of Cooperative, Industry, and Trade of Batu City who related to program Tourism Village;

4. Officials of Department of Agriculture of Batu City who related to program Tourism Village;

The secondary data in this research is the document, reports, archives, or everything that related to Tourism Village and its development, especially in Batu City. The data will be collected from the departments that associated with this program. This research used a qualitative method.

\section{RESULTS}

\section{Implementation of Community-Based Tourism (CBT) in Sidomulyo Tourism Village}

Tourism village is a rural area that offers the whole atmosphere that reflects the authenticity of the village both in social and economic life, social culture, customs, daily life, the architecture and structure of the village spatial characteristic, or economic activities are unique, interesting. It is mean that the village has the potential to develop various components of tourism, for example: attractions, accommodation, foods and beverages, souvenir, and other travel need.

Government has made a policy regarding the implementation of the tourism village through the Minister of Culture and Tourism Regulation Numbers KM.18/HM.001/MKP/2011 of National Program for Community Empowerment in Tourism. These regulations describe how the implementation of that program involves the concept, strategy, and implementation phases of the program in order to realize a reliable and community independent in tourism business. 
Implementation of the national community empowerment program of tourism as described in these regulation is a program from the central government directly to conduct a review into the village that has the potential in tourism. In addition, this program has the goal to reduce poverty in rural communities, especially in the village which has a tourism attraction and the surrounding villages are in the tourism business. Here some of the recipient criteria for national community empowerment program of tourism which is setted by the central government:

a. Villages/ wards which have the potential of tourism and has been visited by tourists;

b. There are at least $20 \%$ of the poor communities who live in rural/ village;

c. Already have tourism activities;

d. Prioritized villages that had a Village Medium-Term Development Plan or village strategic plan; and

e. Prioritized rural/ villages that have implemented a national community empowerment program tourism from another field and have a social organization that fairly active.

The two market characters mentioned above, the development of rural tourism in Batu Sidomulyo is tend to the first marke character, namely the involvement-non incentives. This is because the tourists who visit are not directly involved in rural tourism activities, but they only become as subject to travel, not as a main subject in the tourism village involvement. In Sidomulyo, tourist activity in accordance with the purpose of each individual is for recreation and enjoying travel, while the subject of the main actors is Sidomulyo village communities themselves.

The second is the development of tourism village product with the aspect of usability and quality to attract tourists who visit. Therefore, management should emphasize the development of rural tourism in tourist motivation character with reference to the uniqueness and quality of the product. What is meant by the uniqueness is the search for new things or develops new attractions and more challenging. While, the quality aspect is the search for attractions or activities that reflect to the active participation of tourist. In this case, the development of tourism village Sidomulyo can be done with give attention to the product so that make the tourists interested to visit. Quality of products produced by flowers farmer in Sidomulyo should be increased and enlarge the types of flower.

The third is the development of tourism village that pay attention in aspects of the tourism resource conservation. Given that the development of rural tourism is based on the natural and cultural tourism resources, then pay attention to these aspects is important in developing a community-based rural tourism (Hadiwijoyo, 2012). Sidomulyo tourism village more emphasis on tourism natural resource, therefore it has become a liability for the actors of tourism village that is public, private, and government to maintain the nature sustainability. This is the main capital for tourism village to continue, develop and improve the lives from tourism village industry. Maintaining the sustainability of natural resources owned Sidomulyo tourism village can be done with various efforts with made jointly by all stakeholders. For example, government creates a program for plant maintenance which is also assisted by the CSR funds from private businesses and then carried out by the community Sidomulyo. 
Rifka Aulya, dkk, Strengthening Local Economy Through Community-Based Tourism In Governance Perspective (Study at Sidomulyo Tourism Village, Batu City) $\mid \mathbf{2 1}$

Based on research and surveys conducted by UNDP in Hadiwijoyo's book (2012, p. 84-86), there are two approaches in the development of tourism village is from the perspective of the market and physical of tourism village. In the development of tourism village through market approach is categorized into three (3) interactions they are direct interaction, half direct, and indirect.

a. Direct Interaction

Direct interaction in this approach is mean that possible for tourists to stay and spend the night in the tourist village with owned accommodation.

b. Half-direct Interaction

The pattern or form of a one-day trip made by tourists also can be used as the approach in tourism-village development. In this case, tourists can perform daily activities with villagers' tourists travel directly though just stop and do not live or stay with the locals.

c. Indirect Interaction

Development model of rural tourism tourists is done without having to go to the village, but the community receives indirect benefits such as the writing of a book that tells of the tourist village, a tourist village community life, the history of the village, making of postcards with images of typical craft in their area or traditional dance, and so on.

Sidomulyo tourism village development can be done by considering three such interactions. In direct interaction means that tourists can stay longer in the area of tourism and this can be realized by improving the accommodation facilities in the Sidomulyo village. In the middle of village there are already lodging Villa Watu Mas who became one of the favorite places tourists who want to stay longer because it offers a natural landscape in the form of a beautiful flower plantations so that visitors can also walk to enjoy the sights. In its development, it is not necessary additions to the building area for hotel or inn that may lead to agricultural land conversion into building accommodation. Therefore, an alternative that can be done is by providing homestay from villager's house are made as comfortable as possible so that the tourists can stay longer.

The half-direct development model interaction has the meaning that tourists only visit one day to do sightseeing and not to stay longer. Development through this model can also be done in Sidomulyo considering the attractions that offered by this tourism village is not too much. However, that must be considered in the development of this is how the effort to create the impression for tourists so that they would come back at a later date or someday. The indirect models can also be done in the development of Sidomulyo flowers tourism village with pay attention to natural resources, especially in flowers as icon of this village. By telling the beauty of the village and create a website or a brochure containing tourism village attractions Sidomulyo will bring benefits for tourists who have never visited before. With the information that is made in the electronic media, internet technology, and brochures, this will be a reference for tourists who want to do destinations.

Development of community-based tourism in the perspective of local autonomy is a manifestation of interconnectivity in society who carried out independently by the structure 
itself in order to improve the quality of the preservation order to maintain the natural and cultural values of localities, as well as natural attractions and cultural tourism. So far, local tourism development aimed at developing local potential sourced from natural, social, cultural or economic in order to contribute to the local government, while improving social welfare. Related to the above, the current tourism development planning using community based development approach with emphasis on the empowerment of local communities. In this case the local communities are the subject who will build, own and manage direct tourist facilities and services, so that people are expected to receive economic benefits directly.

Sidomulyo tourism village development can be seen that there is good cooperation between the government and local community and the private sector. Although no direct cooperation by the government with the private sector, but the presence of the private sector is also influencing the development of rural tourism for example, the existence of the bank by providing loan funds and the industry is able to open up employment opportunities for people. Krishna (2003) assumes that when civil society organizations such as farmer associations, youth, women's organizations, and community groups can be involved in public decisionmaking, then they can be a powerful instrument for the creation of a democratic governanve. That is because they were able to boost the local support and safeguard the interests of groups and citizens as well as expand the access in decision making. Civil society organizations can also increase citizen awareness of government programs and provide services to the poor. It also plays an important role in creating political awareness among the public (Cheema, 1983). Development in sustainable tourism can not be implemented if the institution (government) didn't corporate with other stakeholder, such as private sectors. Therefore, in making decisions related to tourism development the government should discuss with all the actors (stakeholders) so that no one will be damaged. In this case, the state has role in creating political and legal environment which is conducive, while the private sector has a role in creating jobs and income, and non-governmental organizations play a positive role in social interaction, economic, and political, including the group invites the community to participate in activities economic, social, and political.

\section{Role of Government}

In Sidomulyo community-based tourism implementation, government of Batu City is not the only actor who dominates in the implementation within governance perspective, but also gives an opportunity to the public and private sectors to participate in tourism village development. Therefore, it needs the cooperation and synergistic interaction between these three actors. It is also explained by Rondinelli and Cheema (2007) who stressed that cooperation between government, private sector, and civil society have become important factors in developing and expanding the service network, expand facilities, as well as providing a wide range of basic services such as health, education, and etc. A partnership between government and the private sector can be done by various mechanisms, among others, through contracts and concessions, build-to-transfer (build-operate-transfer), as well as joint efforts such as public private partnership. 
Rifka Aulya, dkk, Strengthening Local Economy Through Community-Based Tourism In Governance Perspective (Study at Sidomulyo Tourism Village, Batu City) $\mid 23$

As described by Dredge and Jenkins (2007) that the government should (legislative) appointed as representative of the community is able to create a policy and planning as development efforts to involve all stakeholders in the decision-making process. In addition, the government also involving other actors to discuss social issues that are going on, as well as policy content that will be set later. This is done to prevent their individual interests are included in the policy-making process and impartially one of the stakeholders. In good governanve, the government as the legislature should be closer to the citizens and residents of the community and private involving both women and men, young and old groups without discrimination. This is also done by Batu City by involving community in any policies that will be implemented in the development of tourism village in Sidomulyo. Community involvement in the decision making up to the implementation of the program would minimize obstacles that will be faced and to minimize the possibility of conflicts that can occur.

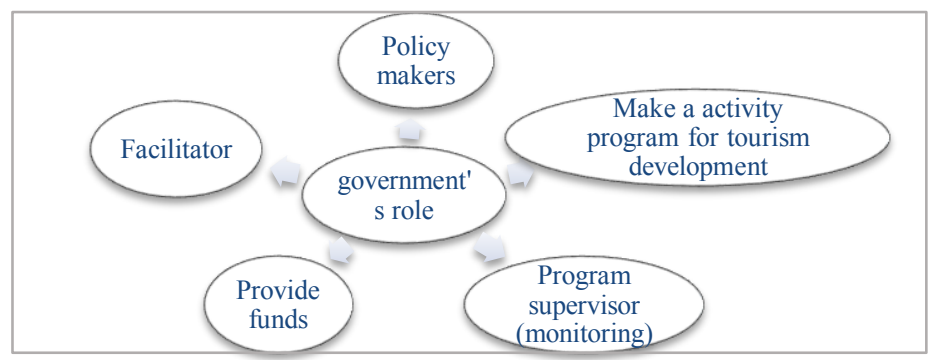

Figure 1 Government's Role in Sidomulyo Community-Based Tourism Development Source: Analysis Result

Based on the picture above, we can conclude that the role of Batu local government in the development of Sidomulyo community-based tourism is as policy makers, financiers, facilitators, program supervisor, and as an actor that makes the program activities. The role of Batu City government will determine implementation of tourism villages in order to develop and improve the standard of living better for Sidomulyo communities.

\section{Role of Private Sector}

In creating good governance, private sector plays an active role in fostering economic activities which will expand employment and increase income. Involving the private sector in governance according to Shameen (2000) was to reduce the dominance of the public sector and improve the competence of a state to maintain economic stability. Private sector is an actor which includes private companies that are active in the market interactions such as: industry trade, banking and cooperatives, and so on. The private sector plays a role in managing and organizing domestic companies both large and small, by mutual agreement. In relation to tourism development, private sector role in providing employment, assisting the government in the provision of facilities and infrastructure supporting tourism, and acted as market participants 
that can be used as a distribution of the products of the local communities. In Sidomulyo development tourism village, private sector can contribute especially in terms of capital. Many people and farmers who borrow funds to private banks. Not only the banking sector, but private companies also become one of the goals of the production of flowers produced by farmers. Deliveries are done to some of the flowers entrepreneur, event organizer, and others can contribute to increasing farmers in improving productivity. The quality of the product and flower seeds produced by Sidomulyo farmers also believed in some areas of both the local and national.

Contribution from private sector is not only as an object of the tourism village, but also able to provide employment opportunities for local communities. For example, the private businesses operating in the sector of accommodation and restaurants will provide jobs as a clerk or employee to local community. The number of restaurants, hotels, inns, and villas can give benefit to Sidomulyo communities either directly or indirectly. Therefore, the role of the private sector is not only as providing CSR funds directly to implement development programs, but also provide job opportunities for the population.

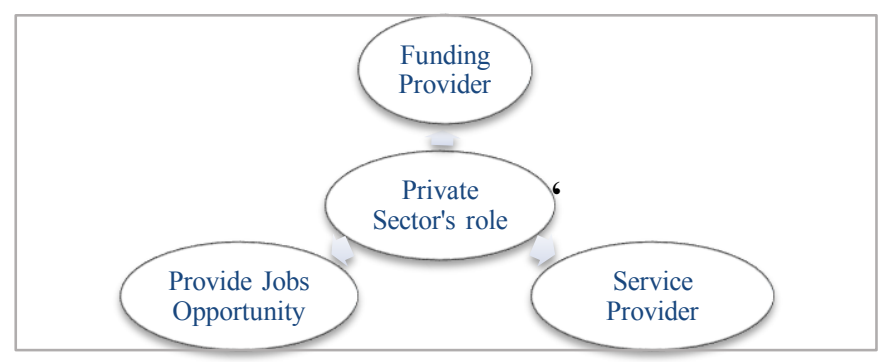

\section{Figure 2 Private Sector's Role in Sidomulyo Tourism Village Development}

Source: Analysis Result

Based on the picture above, it can be concluded that the role of the private sector in the development of community-based tourism Sidomulyo includes three things: as a provider of loans to the community, service providers and provide employment opportunities. The role of the private sector is directly and indirectly can give contribution positively to the development of tourism village in Sidomulyo.

\section{Role of Civil Society}

Successful development of CBT depends on various factors. One is the support or participation of local communities. The involvement of local communities in this context implies that the development of a tourism attraction in the village should be developed from the community, by the community and for the community. Therefore, the participation of rural communities is absolutely necessary in order to determine the direction of the development of a tourist destination, helping empower community resources to provide jobs or create jobs for local people, to avoid the appearance of conflict of interest between local communities and the developer of a tourist attraction, avoid social inequality, and as an institution of control in the 
Rifka Aulya, dkk, Strengthening Local Economy Through Community-Based Tourism In Governance Perspective (Study at Sidomulyo Tourism Village, Batu City) $\mid 25$

exploitation of natural resources and cultures of local communities excessively. The level of involvement of local communities in a tourism attraction with another tourist attraction will be different depending on the capabilities of human resources (HR) development of local communities in tourism attraction areas. Based on the results of field research on the various components of the community in the village Sidomulyo have shown the involvement of local communities in planning the development of tourism destinations in the village Sidomulyo. Not only their participation in each activity and the policy making process, the role of Sidomulyo community also evident from their efforts as the subject of tourism is to do things well in order to contribute to the tourism village development. At the community level, active participation is an important element in the formulation of development plans in order to raise confidence and develop a sense take responsibility for the results of community-based tourism development.

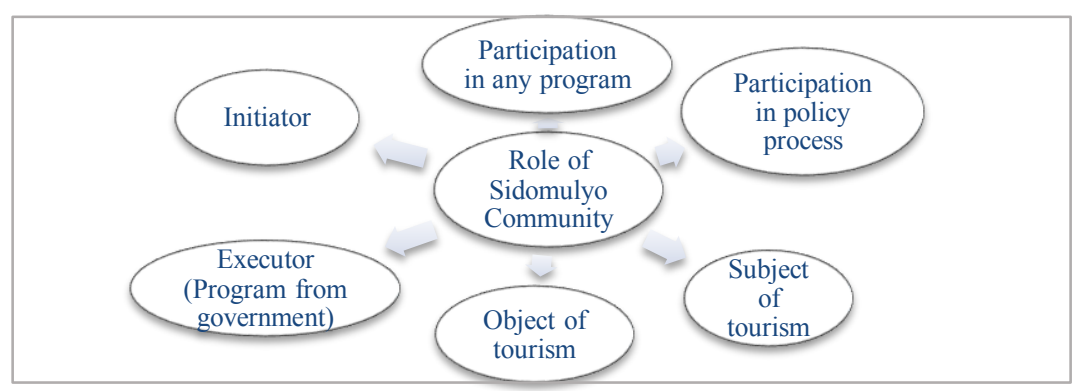

Figure 3 Community's Role in Sidomulyp Tourism Village Development

The picture above shows that the role Sidomulyo community is very active in community-based tourism development. It can be seen from their participation in some activities. As the subject of tourism, it can be seen from the enthusiasm of people participate in various activities and programs of the government as well as their innovation in improving the quality of production. Meanwhile, tourism object, it can be seen from their role in conserving and providing the best service to the tourists who visit.

Target and the objective of the tourism village is to create a society that is independent and able competitive with the other regions. In addition, the development of rural tourism destination in Batu City is an attempt to increase the potential of the village which can improve local people's income from tourism businesses. Based on the statement of Mr. Mulyo Adji as the Head of Training and Development Section at the Department of Tourism and Culture of Batu City states,

"We actually want that the tourism village is expected to improve the local economy and tourism potential in the village. Batu City has a village with a variety of different potentials to other villages, like in Sidomulyo known for ornamental plants. With greatly support from all stakeholders, promotion and community participation, I believe that the tourism village communities will be independent and prosperous. Tourism village also became one of the efforts to increase competitiveness and to improve the creativity of its people". (Interview in October $\left.8^{\text {th }}, 2015\right)$ 
26|Ad'ministrare, Vol. 3 No. 2, 2016

Based on an interview with Mr. Mulyo Aji, it can be explained that the purpose of the establishment of a tourism village is:

1. Improve the social economy. Referred to improve people's economy is able to increase the people's income derived from their efforts (self-reliance) on their own. In accordance with the concept of LED that local economic development can be achieved due to the efforts of local people who play an active role in economic development (economic activity). Various kinds of government programs that have been conducted with stakeholders involved in tourism village development is to encourage local and international tourists to know better the natural resources, culture, and traditions of the people in the village Sidomulyo. Through tourism village, the community is expected to introduce the traditions, potency, and local culture to the wider community and raised economy of the community around the village.

2. Increasing community participation in development. Either directly or indirectly, the tourist village is able to encourage the development of a region. With rural incomes increasing, it will also be able to increase local revenue. If the income of society is increasing, then they will get motivated to further innovate in all tourism activities in the village. With the development of rural tourism, the participation of the surrounding communities is empowered as much as possible. The development of rural tourism means tourism development involving community resources that exist in tourist areas and surrounding areas.

3. Creating job opportunities. Since the enactment of tourism village in Sidomulyo was able to open up employment opportunities for rural communities. Many residents set up food stalls and other stalls, many people who sell various kinds of fried, and other small shops. Villagers Sidomulyo also the more open flowers shop for the tourist and also for the agents who have become permanent customers.

4. Increase the potential of the village. The enactment of Sidomulyo as a tourism village is able to improve the creativity and innovation of local communities so that can increase the potential that exists in the village. Sidomulyo flower tourism village has been known for the quality of flower products produced and friendly people. By harnessing abundant natural resources in Sidomulyo village, rural communities are now beginning to optimize in tourism sector and build flower tourism village area becomes more attractive with many attractions and natural beauty provided.

5. Improving the competitiveness of the village. Revitalization of the tourism sector through the development of rural tourism is expected to be one of the alternative strategies to enhance the competitiveness of tourist destinations in terms of tourism development in Batu City and improve competitiveness Sidomulyo village with other tourism destination in the other area.

6. Realizing agro-based tourism. One of the vision Batu City is to realize the agriculturebased tourism or commonly known as Agro-tourism. With its potential, agriculture is an important sector of Sidumulyo society to create an employment and provide income for 
Rifka Aulya, dkk, Strengthening Local Economy Through Community-Based Tourism In Governance Perspective (Study at Sidomulyo Tourism Village, Batu City) |27

them. Development of agricultural area into agro-tourism area will increase the tourist visitation which will contribute to an increase in the public opinion of tourist services.

The main target of the Batu city government in the development of rural tourism is poverty alleviation that occurring in Sidomulyo society. Poverty alleviation through improving economical income of local communities can be made with the implementation of the tourism village optimally and must supported by all relevant stakeholders. Key success in the implementation of tourism village is the role of its own society (community participation). Therefore, the target of the implementation of tourism village is also to increase the participation of local communities in order to increase the potential of the village. It is also said by Mr. Suwoko, as the field head of economics in Regional Development and Planning agency of Batu city,

"Tourism village is to actually reduce poverty. Thus, various kinds of activities/ programs implemented by the government in developing a Tourism village is an effort to improve the local economy. Not only that, because of tourism village is managed by the villagers themselves, so we were able to increase community participation in development. If the tourism village is successful, it can be said that the village has been able to compete with other villages" (Interview in September 23 ${ }^{\text {rd }}$ 2015)

\section{CONCLUSION}

Tourism sector has made Batu City experiencing rapid economic growth and become one of the most visited tourist destinations both domestic and foreign tourists. Even the tourism sector is able to stimulate the growth of other industries such as the industry of souvenirs, handicrafts, culinary, hospitality, restaurant and others. One of the famous tourism destinastion in Batu City is Sidomulyo tourism village. Sidomulyo Tourism Village offers natural tourist attractions with excellent products in the agricultural sector and the diversity of flower types produced. Implementation of the tourism village Sidomulyo can not be separated from the role of relevant actors, namely the government, private sector and communities themselves. These three actors contribute highly in Sidomulyo tourism village development process to become one of the popular destinations to the tourists.

Development of Sidomulyo tourism village being implemented with the concept of community empowerment or what is known in the world of tourism as a community-based tourism. This is also become the the purpose of village tourism development is to promote rural tourism based on local community empowerment; create an innovative human; create jobs; reduce poverty; forming an independent and resilient society; created man who can innovate; and improve cross-sector cooperation in the tourism village development. With an emphasis on community empowerment, it will boost their self-reliance and creativity in developing the tourism potential in Sidomulyo. In other words, tourism village development with community empowerment will have an impact on improving the local economy, increase local revenues from tourism and marketing are increasingly widespread. Aside from being able to increase revenue, the concept of community empowerment in the development of tourism village can 
28|Ad'ministrare, Vol. 3 No. 2, 2016

improve life quality of local communities and gives chance for the next innovation of the product that will be created.

Tourism village in Sidomulyo had given a positive impact on economic development, both on a local up to national scale. The potential of tourism in Sidomulyo village has made a significant contribution to the local revenue. Tourist attraction that owned by Sidomulyo tourism village have ability to attract tourists to visit them. Tourism is a key for socio-economic progress. Tourism can also increase export revenues. Tourism sector also contributed positively in improving the economy of local communities and the national economy. More and more tourists are visiting, then the income will increase, it will then need more workforce so it will provide job opportunities for the community. In addition, the tourism industry will ignite the growth of small entrepreneurs such as artisans, painters, photographers, souvenir shop, gift center, and so on. Directly or indirectly, it will affect people's incomes and will be able to take advantage of opportunities for the tourism industry. However, the implementation of tourism village in Sidomulyo still facing some obstacles such as the lack of regulations governing the implementation of the tourism village and the lack of adequate facilities for both tourism actors as well as facilities for tourists. Thus, it takes some strategies that can be done for the development of Sidomulyo tourism village in order to become one of the tourist destinations that attract many tourists. Absoulety, the strategy will be achieved if carried out with the cooperation from the relevant stakeholders.

\section{REFERENCES}

Alipour Habib, et. al. 2011. Governance as Catalyst to Sustainable Tourism Development: evidence from North Cyprus. Journal of Sustainable Development Vol.4 No. 5, October 2011.

Angrosino, M.V. 2007. Doing Etnographic and Observational Research. Thaousand Oaks, CA: Sage.

Arieta, SIti. 2010. Community Based Tourism pada Masyarakat Pesisir; Dampaknya terhadap Lingkungan dan Pemberdayaan Ekonomi. Jurmal Dinamika Maritim Vol. 2 No. 1.

Blakely, E. J. \& Bradshaw,T. K. 2002. Planning Local Economic Development; Theory and Practice, ThousanOaks, London, New Delhi, SAGE Publications.

Brohman, J. 1996. New Directions in Tourism for the Third World. Annals of Tourism Research. 23(1):48-70:60.

Cheema, G. Shabbir. 1983. The Role of Voluntary Organizations in Decentralization and Development: Policy Implementation in Developing Countrie. Beverly Hills: Calif. Sage.

Corbin, J. and Strauss, A. 2007. Basic and a Qualitative Research: Techniques and Procedures for Developing Grounded Theory $3^{\text {rd }}$ Edition. Thousand Oaks, CA: Sage.

Creswell. Jhon W. 2009. Research Design: Qualitative, Quantitative, and Mixed Methods Approach. Third Edition. Sage Publication. California

Creswell, Jhon W. 2013. Penelitian Kualitatif dan Desain Riset; Memilih di antara Lima Pendekatan, Edisi ke 3. Yogyakarta: Pustaka Pelajar.

Damanik, Janianton. 2005. Poverty Solving with Tourism. Yogyakarta: Kepel 
Rifka Aulya, dkk, Strengthening Local Economy Through Community-Based Tourism In Governance Perspective (Study at Sidomulyo Tourism Village, Batu City) |29

Dredge, Dianne and John Jenkins. 2007. Tourism Planning and Policy. Singapore: Fabulous Printers Pte. Ltd.

Graham, J., Amos, B., \& Plumptre, T. (2003). Governance principles for protected areas in the $21^{\text {st }}$ century. Ottawa. ON: Institute on Governance.

Hadiwijoyo, Suryo Sakti. 2012. Perencanaan Pariwisaata Perdesaan Berbasis Masyarakat (Sebuah Pendekatan Konsep). Yogyakarta: Graha Ilmu.

Hendratno, Edie Toet. 2009. Pertumbuhan Pemerintah Daerah di Negara Republik Indonesia. Yogyakarta: Liberty.

Irawan \& Suparmoko. 2011. Ekonomi Pembangunan Edisi Keenam. Yogyakarta: BPFE.

Krishna, A. 2003. Partnerships between Local Governments and Community-Based Organizations: Exploring the Scope for Synergy. Public Administration and Development 23: page 361-71.

Lincoln, Yvona S., \& Egon G. Guba. 1985. Naturalistic Inquiry. Beverly Hills: Sage Publication.

Moleong, Lexy J. 2000. Metodologi Penelitian Kualitatif. Bandung: PT Remaja Rosdakarya Offset 2009. Metodologi Penelitian Kualitatif. Bandung: PT Remaja Rosdakarya Offset 2014. Metode Penelitian Kualitatif Edisi Revisi. Bandung: PT Remaja Rosdakarya.

Muluk, Khairul. 2009. Peta Konsep Desentralisasi \& Pemerintahan Daerah. Surabaya: ITS Press.

Nazir. 2005. Metode Penelitian. Bogor: PT. Ghalia Indonesia

Osborne, D., and Gaebler, T. (1993). Reinventing Government: How the Entrepreneurial Spirit Is Transforming the Public Sector. New York: Plume/Penguin Books Wahab, Salah.1975. Tourism Management. London: Tourism International Press

Patton, Micahel Quinn. 1987. Qualitative Evaluation Methods. Beverly Hills: Sage Publication.

Pedrana, Margherita. 2013. Local Economic Development Policies and Tourism; An Approach to Sustainability and Culture. Regional Science Inquiry Journal, Volume V. (1). Page 9199.

Pendit, Nyoman S. 2006. Ilmu Pariwisata (Sebuah Pengantar Perdana). Jakarta: PT. Pradnya Paramita

Pitana, I Gde \& Putu G, Gayatri. (2005). Sosiologi Pariwisata Yogyakarta : CV Andi Offset

Raharjana, Destha Titi. 2010. Membangun Pariwisata Bersama Rakyat; Kajian Partisipasi Lokal dalam Membangun Desa Wisata di Dieng Plateau. Jpurnal of Kawistara.

Ramukumba, Takalani. The Local Economic Development in the Eden District Municipality, Western Cape Province, South Africa: A Case Study of Emerging Entrepreneurs in Tourism Industry. American Journal of Tourism Research Vol. 1, No. 1, 2012, 9-15.

Republic of Indonesia. 2014. Undang-Undang Nomor 23 Tahun 2014 tentang Pemerintahan Daerah. Lembaran Negara Republik Indonesia Tahun 2014 Nomor 244. Sekretariat Negara. Jakarta 
30|Ad'ministrare, Vol. 3 No. 2, 2016

Rodriguez-Pose, A., 2001: The Role of the ILO in Implementing Local Economic Development Strategies in a Globalized World, Unpublished paper, London: London School of Economics.

Rondinelli, Dennis A. and Cheema, G. Shabbir. 2007. Decentralizing Governance; Emerging Concept and Practice. Washington DC: Brookings Institution Press

Sabarno, Hari. 2008. Memandu Otonomi Daerah; Menjaga Kesatuan Bangsa. Jakarta: Sinar grafika.

Sedarmayanti. 2003. Good Governance (Kepemerintahan yang Baik) Dalam Rangka Otonomi Daerah; Upaya Membangun Organisasi Efektif dan Efisien Melalui Restrukturisasi dan Pemberdayaan). Bandung: Penerbit Mandar Maju.

Soekadijo, R.G. 2000. Anatomi Pariwisata. Jakarta: Gramedia Pustaka Utama

Sudantoko, H. Djoko. 2003. Dilema Otonomi Daerah. Yogyakarta: Andi Offdet:

Sugiyono. 2009. Metode Penelitian Kuantitatif dan Kualitatif dan R\&D. Bandung: CV Alfabeta Surachmad, Winarno. 1993. Pengantar Penelitian Ilmiah. Bandung: Tarsito

Stoker, Gerry and Chhotray, Vasudha. 2009. Governance Theory and Practice; A crossDisciplinary Approach. London: Palgrave Macmillan.

Sumarto, Hetifah Sj. (2009). Inovasi, Partisipasi dan Good Governance; 20 Prakarsa Inovatif dan Partisipatif di Indonesia Edisi Kedua. Jakarta: Yayasan Obor Indonesia.

Suwantoro, Gamal. 1997. Dasar-Dasar Pariwisata. Yogyakarta: Andi Publishing

Yoeti, O. A. 1997. Perencanaan dan Pembangunan Pariwisata. Jakarta: PT. Pradnya Paramita. 2008. Perencanaan dan Pembangunan Pariwisata. Cetakan Kedua. Jakarta: PT.

Pradnya Paramita 